\title{
Value Expression of Traditional Culture Elements' Digital Development in Modern Animation Film and Television Art
}

\author{
Yu Wang \\ Huanghe Science and Technology College \\ Zhengzhou, China 450000
}

\begin{abstract}
Up to now, Chinese traditional culture is presenting its unique artistic charm with diversified forms. More flexible and diverse development trend is presented by combining traditional culture and modern technology. In the creation of animation film and television works, China's animation film and television industry has achieved great success in this era of digital development by referring to traditional culture of China. For example, the success of "Mulan," "Kung Fu Panda" and other animation television works, has won the broad market for the animation film and television art works with traditional culture elements, and has pointed out new development direction for animation designers. With the advent of digital age, there are more ways and means for the spread and development of traditional culture, more and more traditional cultural themes are made into animation film and television works, which are well-loved. Thus, it can be seen that the development of animation film and television industry should not only focus on technical issues, but shall also pay attention to cultural connotation of the works. Since the brilliance of "Chinese School", there have almost no animation films with high quality yet without age limitations in China to cope with the global animation film development trend and people's changing cultural needs. The excellent domestic animation films, such as "Monkey King: Hero Is Back", "Little Door Gods" and "Kuiba" released in 2015 , like a strong cry, showing the heavy counterattack of domestic animation. The remodeled form of traditional culture has broken this deadlock accidentally. It has interpreted the new generation of animators' understanding of traditional themes and modern animation film from the perspective of breakthrough of role modeling at that time and the perfect integration of fashion and traditional culture, which is an attempt of transformation of modern Chinese animation film, and has provided reference prototype for its further development.
\end{abstract}

Keywords-traditional culture; modern film and television; animation film; digital development; value expression

\section{INTRODUCTION}

Development of traditional culture needs to combine culture and modern economics as well as social development together. Therefore, it is necessary to add modern meaning to the traditional culture. The characteristics of cultural heritage and development is to make innovation on film and television animation when they are reflected on digital animation film and animation, and the aforementioned innovation is not only the innovation on the technology of playing means, what's more important is to add the novel culture that meets modernization into it. Digital expression of traditional culture is insufficient, having a large gap with that of foreign countries, and main reasons are the lack of talents and insufficient education ability. As a result, a large number of talents need to be introduced for the advanced animation film and television production art. Display the contents of film and television works with traditional Chinese cultural thinking, enhance the integration of traditional culture and animation film and television works using modern information technology, pay attention to grasp the meaning of traditional culture and raise it to the modern expression. Therefore, the development trend of modern cultural development and prosperity is to carry forward the traditional culture and integrate modern culture and traditional culture.

Year 2015 can be referred to as the good harvest year of Chinese local animation film. Several domestic animation films that released in theaters have been praised in terms of box-office and reputation of the evaluation. This paper takes "Monkey King: Hero Is Back", "Little Door Gods" and "Kuiba" series domestic animation films as the main research objects, and especially makes in-depth internal research on the appearance of "breakthrough" of box-office made by domestic animation films, discusses the "breakthrough" of domestic animation film from data analysis, industrial standard and content creation, and provides corresponding reference opinions for the industrial development of domestic animation film in the future.

\section{EXPLORATION OF THE IMPORTANCE OF TRADITIONAL CULTURE ElEMENTS' DEVELOPMENT IN MODERn FILM AND TELEVISION ART}

The digitalization of traditional culture has brought more opportunities for the development of animation film and television industry. Enhancing the actual value of animation film and television industry from the height of cultural strategy as well as taking the digitalization of traditional culture as opportunity has brought the possibility for the innovation and development of animation film and television. Achieve the industrialization scale of traditional culture, realize the mutual support development in cultural industry, carry forward 
Chinese nation's traditional culture in animation film and television industry, enable the world to feel the charm of Chinese culture, convey China's cultural thoughts, deepen the connotation of traditional culture constantly, and achieve the inheritance and innovation of traditional Chinese culture from the development sight of the times. Digitalization of traditional culture is a new cultural experience, contacting more contents of traditional culture with brand new cultural form, which can meet the public's demand for traditional culture, satisfying humanistic sensibility and national feelings. Traditional culture is a kind of culture complex, which can bring the souls experience whole leading the public to enhance visual culture enjoyment. Therefore, paying attention to the combination of traditional culture and modern film and television animation technology is of very important practical significance.

Integrating traditional art language into modern film and television animation has been a kind of unique culture in film and television animation circle. A series of modern film and television animations have become popular quickly due to integration of tradition art language. Now, many traditional art languages have been integrated in China's modern film and television animation, and this form has attracted more and more extensive attention from the international film and television animation circle. Traditional art language culture has been integrated in a lot of modern film and television animation works both at home and abroad, which has promoted the integration of modern film and television animation with traditional art language to a large extent. This paper will mainly discuss the concepts of modern film and television animation, the application of traditional art language in modern film and television animation, the importance of applying traditional art language into modern film and television animation, as well as the integration of modern film and television animation and traditional art language.

\section{Traditional CUlture ElEmENTS' Digital EXPRESSION FORMS IN MODERN FILM AND TELEVISION WORKS}

Traditional culture is of rich cultural content and profound cultural heritage, which is more diverse in terms of expression forms. The technologies of ink painting, Peking opera and shadow puppets are integrated in terms of modeling design of the characters, mould different characters using traditional Chinese clothing and hairstyle characteristics, to meet the aesthetic needs of modern people. As for the deployment of colors and the setting of story plots, more creative development is made in the stories in traditional culture. The main colors in traditional Chinese culture are red, yellow and other colors, representing traditional Chinese culture by virtue of such representative colors. As for sound effect and music, traditional instruments' playing is integrated in it, enabling the public to feel the perfect combination of traditional culture and modern technology. The classical music elements in traditional music can bring people more visual enjoyment, people can feel the traditional culture's profound culture connotation through music, while the appropriate music content can enhance people's perception of traditional culture, deepening artistic works' cultural contents and emotions.

\section{A. Shape Modern Film and Television Role Modeling Using Traditional Art Forms}

Since the brilliance of "Chinese School", Chinese animation film and television works have been trying to break limitation of younger age with high-quality animation film, to cope with the international development trend of animation films and people's changing cultural needs. The excellent domestic 3D animation film of Monkey King: Hero Is Back released in 2015 has broken the deadlock with accidentally by virtue of remodeling the traditional culture. It has interpreted the new generation of animators' understanding of traditional themes and modern animation film from the perspective of breakthrough of role modeling at that time and the perfect integration of fashion and traditional culture, which is an attempt of transformation of modern Chinese animation film, and has provided reference prototype for its further development.

The traditional roles after adaptation have the characteristics of more modernized expression. For example, Sun Wukong looks like an uncle, Jiang Liuer is the child who is entering into this field, the leader of monsters is Hun Dun, and everything is so smooth and natural. From the control of actors' lines we can say it is the most interesting one among domestic animation in recent years.

Jing Liuer: Are the Four Heavenly Kings brothers?

Wukong: They are sisters.

Jing Liuer: Is Nezha a boy?

Wukong: She is a girl.

Jiang Liuer: Does Heaven Marshal Li have a pagoda?

Wukong: NO.

Jiang Liuer: Is any person in the pagoda?

Wukong: Well, no...

This dialogue of "Hero Is Back" is loved by the audiences, as they discuss it with pleasure after they have watched the film, which is full of innocence, yet it is funny. Although these problems are not important, it is a small problem of the audiences who have watched or are still watching "Journey to the West". Jiang Liuer asks them for the fans of "Journey to the West" , but did not get an official and serious answer, yet the audiences do not care about the correctness of the answer, only to review "Journey to the West" from the perspective of Jiang Liuer, explaining their doubts in their childhood and obtaining today's pleasure. A series of "verbose" questions and Sun Wukong's indifferent answers reflect that current the current children are thoughtful yet the adults are impatient. These affecting scenes are the expression of screenwriter's experience of details in life. It can be seen that traditional themes' trans-time-and-space representation in current context is a matter of viewing angle.

"Kuiba" domestic animation film series are the realistically writing animations that are rare in China, of which the character modeling design is of powerful impact with fine screen. Each character has a very high degree of recognition. 
For example, the clothing design of Manji, the leading role, adopts the bright orange, the warm tone, to express the leading role's enthusiastic, positive, progressive character. And the modeling that is exactly like the "Monkey King" also plays a certain role of implication, as Sun Wukong represents the classical rebel image of traditional Chinese culture. In addition, another character, the head of Wowo Village, also impresses the audience deeply. At the beginning of the first volume of "Situation Critical of Kuiba", when the village head reluctantly to conform to the public opinion of chasing Manji and his foster father out of the village, for fear of hurting others' feelings, he said implicitly that "you should go to do bigger business, and this small village shall not set back you", reflecting China's unique thinking and behavior habits. The shaping of characters in "Kuiba" has broken the previous simplification and opera makeup tendency of domestic animation. Creators do not adopt the simply preaching to convey the positive and optimistic attitude towards life, but focus on how to tell a good story, and to express the spiritual content of "benevolence, righteousness, propriety, wisdom, faith" through film narration and fine emotions, so that the audiences can be touched subtly.

\section{B. Digital Adaptation of Traditional Folk Tales in Modern Film and Television Works}

There are a lot of scripts adapted from traditional Chinese stories in modern film and television works. Particularly the film and television works with theme of "Journey to the West" are quite common. The framework of stories of traditional culture has formed the fixed pattern in people's ideology. To enrich characters and innovate the plot are needed for modern film and television animation works. For example, the film and television works such as, "The Monkey King", " Journey to the West: Conquering the Demons", and animation works of "Hero Is Back", "The Grow", have made creative development of the basic characters around the journey to the west, which has formed new presentation of the story.

The creation of animation film and television works under the domain of traditional culture shall take the multiple cultural elements into consideration comprehensively, to achieve imperfect integration of traditional cultural elements, enhance the three-dimensional sense and richness of traditional animation film and television works, to achieve perfection of traditional culture and modern development. "Hero Is Back" is created based on the theme of Journey to the West. However, it does not tell the story about the Monkey King according to the narrative patter known by the public, but it presents "the story of the director, the role of director, and the world of the director". The film does not "consider" the audiences' existing understanding of the story of Journey to the West, but has made large scale adaptation of the story with "courage". Some people blindly hold the opinion of following the tradition, thinking that Monk Tang is the master of Sun Wukong, and the Journey to the West shall tell the story about Monk Tang and his apprentices, as well as monsters and the Heaven. And these episodes have inheritance relationship which is impassable, otherwise it is mischief; however, the new generation believes that anything is possible, time is changing and the society is also changing, and anything is possible as long as it is reasonable. Perhaps just because of the former's hesitation about "should or should not", the formation of modern animation film originality is limited, or perhaps thanks to the boldness and openness of the latter, the integration of fashion and tradition of "Hero Is Back" is constructed successfully. The film does not take pleasing the audiences as the only purpose, for instance, the embedded shadow puppets and Peking opera elements do not please the audience with the form of novelty seeking and funny, but to reflect the creators' re-interpretation of traditional Chinese culture from the viewing range of the development of the times, which is the reflection of carrying forward excellent traditional culture with the responsible feelings. Therefore, it is sufficient to prove that the adaptation of traditional theme by Hero Is Back does not make spoof and mischief.

Setting the external expression forms aside and returning back to the most important point of setting world outlook of the animation film, in the overhead world system of "Kuiba" series, there are very distinctive Chinese fantasy elements. Films have formed a very large fantasy world, known as one of "the most rigorous fantasy animations in China". The film tells that in the Yuan Yang realm, due to the mistake of heaven and earth and the flaw of the universe, a terrible creature named Kuiba appears every 333 years, and it is the important mission and great honor of the warriors both in the heaven and on the earth to destroy Kuiba every 333 years. First of all, the distinctive Chinese elements can be seen from the "Yuan Huan Realm" and the name of characters. In the movie, there is no country in heaven but only five large systems, having their own duties respectively. The five gods belong to "Jing, $\mathrm{Pu}$, Huan, Yan and Chen" respectively, corresponding to the Five Elements Theory in the naive materialism of ancient Chinese Han nationality and the spontaneous dialectics thought, namely gold, wood, water, fire and earth. In traditional Chinese culture, these five images generate each other and restrict each other acting as the origin of life. The universe is generated through the contradiction and unity of birth, control, constraint and reconciliation, balance and unbalance, thus produce the auspicious and ominous things as well as the disaster and blessing. This shows that the creators of "Kuiba" construct "Yuan Huan Realm" using "five elements theory" is of profound meaning.

\section{Value-AdDed Meaning Of Traditional Culture Digital DEVELOPMENT For MODERN ANIMATION FILM AND TELEVISION}

Digital development of traditional culture is of great attraction for the growth of value-added animation film and television industry, the endless cultural expressions can bring more visual and spiritual shock and sentiment to people, broadening people's cultural horizon, making great contributions for the development of traditional Chinese culture with highly expressive forms. The creation of animation film and television in foreign countries is closing to traditional Chinese culture actively, which is the reflection of nationalization of animation film and television. Designers should not only refer to the technology of animation film and television, but also shall refer to the concept toward culture. The economic value of traditional culture is constructed based 
on the realization of cultural value. Traditional culture digitalization is of far-reaching realistic influence on the creation and development of animation film and television. We shall pay attention to innovation points of traditional culture, and treat the development of traditional culture seriously with a kind of cultural responsibility. The innovation of animation film and television shall achieve the interaction with traditional culture, only in this way, can it have a more long-term development, and revitalize the development of traditional culture using Chinese native culture, thus to infuse fresh vitality into animation film and television industry. The application of traditional culture into animation film and television industry, can not only create value in the broadcasting of screen culture, but also can drive the development of support industries. For example, the animation of The Legend of Qin restores the culture, tactics, divination, swordsmanship and other culture of the Warring States period, which is an excellent works in the animation industry in China. The development of film and television cultural books and toys driven by it also brings about economic benefits.

\section{CONCLUSION}

The modernized film and television animation industry development of traditional culture is the new development form of modern film and television animation industry. The development of traditional culture by modern film and television animation is only limited to the superficial extract without sufficient deep-level connotation expansion. Only by displaying the profound connotation of traditional culture can the phenomenon of traditional culture being distorted artificially be changed, and the more extensive extension and expansion in terms of technology and cultural content can be achieved. People's cognition of traditional culture is developed gradually along with the deepening of family education and social education. The development of traditional culture by modern digital film and television industry is not only the copy of traditional culture, but the modern animation film and television shall have a subversion of tradition, or make reference by innovation. As for the current situation of modern entertainment development and China's economic development, the film and television entertainment animation industry shall conduct integration of industrial strength, to concentrate the scattered power of the whole industry to develop China's traditional culture as well as film and television industry.

\section{REFERENCES}

[1] Miao Ziye. Discussion on Integration of Modern Film and Television Animation and Traditional Artistic Language [J].Movie Literature, Vol.23, 2011

[2] Zhou Yuan, Yu Jing. Influence on Chinese Modern Film and Television Animation Design and Production by Traditional Culture [J]. West China Broadcasting TV, Vol.2, 2014

[3] Zhao Yao. Influence on Film and Television Animation Narration by Traditional Culture [J]. Contemporary TV, Vol. 2015

[4] Dai Yunwu, Qiu Changyuan. Discussion on Development Trend of Chinese Animation Film from Hero Is Back [J]. Contemporary TV, Vol. 10,2015 